\title{
Student's Satisfaction Level Towards Teachers' Pedagogical Skills: A Conceptual Action Plan for Sindh Pakistan
}

\author{
Muhammad Mujtaba Asad a , Asif Ali Pitaffi ${ }^{\text {b }}$, Sumaira Zia ${ }^{\text {c }}$ \\ ${ }^{1}$ Department of Education, Sukkur IBA University, Airport Road Sukkur, Sindh, Pakistan.

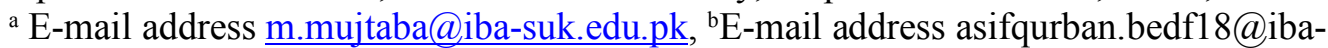 \\ suk.edu.pk, ${ }^{\mathrm{C} E}$-mail address sumairazia.bedF18@iba-suk.edu.pk
}

\begin{abstract}
Pedagogical skills are essential for every teacher to promote the process of teaching and learning and to make it more effective. In this modern era of technology and advancement, pedagogical skills have also become a very important domain of concern among educational institutions. Therefore, this study will focus on the indication of the satisfaction level of students towards teachers' pedagogical skills at government schools of Ghotki Sindh, Pakistan. Whereas, the research design of this study will be quantitative. The respondents of this study will be 200 students from both urban and rural government higher secondary schools of district Ghotki (the statistics are determined by the report of school education data 2016-2017) during the academic year of 2019-2020 will be surveyed for this study. The major aim of this research is to analyze the satisfaction level of students towards the teacher's pedagogical skills. Moreover, a survey questionnaire will be adapted for this study based on previous researchers' contributions. The descriptive (Mean and Standard Deviation) and inferential statistical (Independent sample T-Test and Mann-Whitney U approaches will be utilized by using SPSS 22 software for data analysis of this proposed study. The outcome of this study will contribute to the specification of effective pedagogical skills of teachers and the level of satisfaction among urban and rural students of Ghotki, Sindh. The findings of this study will help teachers to work and improve their deficiencies in their teaching methods and approaches.
\end{abstract}

Keywords Pedagogical Skills, Pedagogical Content Knowledge, Teaching strategies, Instructional Assessment, Classroom Management, Knowledge of Curriculum, Urban, Rural, Satisfaction Level.

\section{INTRODUCTION}

In today's' classrooms, the role of students has gained more significance and they have been given more empowerment as a paradigm shift in the education system. This shift introduced the concept of students' satisfaction that has become a matter of consideration for recent several years and now has become an integral part of the nation's educational objectives (Leyla Temizer et. al, 
2012). Nowadays, the quality teaching is being regarded as a product of educational institutions that are used to attract the valued customers (students) and to obtain their satisfaction to increase the market value (attracting new students and maintain the existing ones) and to gain reputation in the market (education system) (Leyla Temizer et. al, 2012 \& Shinn, Yun Ho 1997).

Many researchers have mentioned that students are capable enough to reflect on the teacher's method of teaching, instructional assessment, and classroom management skills. Thus, students are eligible to express whether they are satisfied with the teaching methods of their instructor or not. Keeping this in view, one of the key aspects that require students' satisfaction in claiming the provision of quality teaching is the teacher's pedagogical skills. As such, the influence of teachers' pedagogical skills on students' academic achievement and participation in classroom activities has always been regarded as an important factor in imparting quality education. Illustrating more, concerning National Education Policy 2019 (P No. 10) and National curriculum for 2019 (Ch. No. 5 ) the focus on teachers' professional development and effectiveness in teaching by developing their pedagogical skills is one of the major concerns. But as a matter of fact, students' satisfaction towards teacher's pedagogical skills and teaching methods had never been taken in to account as a matter of importance and usually never paid attention by the educational authorities (M. Nauman et. al, 2010).

In the context of Pakistan and particularly of Sindh, many of the studies have been done on finding ways to improve the quality of higher education, unfortunately, no significant study has yet made to address the issue of students' satisfaction level towards teachers' pedagogical skills. As a result, the underprivileged areas like interior Sindh and more specifically district GHOTKI are left behind in upgrading the professional growth and developing the required skills of their teachers, and thus they never had pondered over on the significance of students' satisfaction in this regard. Due to this ignorance and negligence, both of the prime members of the education system (student and teacher) are meeting the adverse consequences. Therefore, the study of the satisfaction level of Students towards teachers' pedagogical skills is ought to be investigated to make quality reforms and to provide essential information to the concerned authorities.

\section{LITERATURE REVIEW}

Students' satisfaction has become a matter of importance and attraction for educational institutions these days (Leyla Temizer et. al, 2012). The shift of classroom practices from teachercentered to student-centered has empowered the students to express their satisfaction and dissatisfaction with their learning experiences. Shinn, Yun Ho (1997) stated that the development and advancement in teaching practices didn't only strengthen the education system but also raised the status of students to the valued- customers. Therefore, it has become very necessary for teachers to satisfy their students by offering such services that help them in fulfilling their expectations from their learning experiences and the education system. Suarman (2015) reported that the quality experience of teaching and learning has a greater influence on students' satisfaction. This is consistent with Techachaicherdchoo Teerawut (2011) that the more the students are satisfied, the more they have positive feelings for their institution. Whereas, the dissatisfaction of students towards their learning experience affects both the student-institution relationship and students' academic performance adversely. According to (Leyla Temizer et. al, 2012) the growing emphasis on attaining students' satisfaction discloses that the educational institutions have started a deliberate competition amongst each other in which they all are striving to maintain their quality of education for a good reputation.

There are various domains in which the students' satisfaction can be reported. Amongst, the most crucial one is the satisfaction towards teaching methods and skills of the instructor. Shinn, Yun Ho (1997) highlighted that the exploration of students' satisfaction towards teaching skills is not a one-take shot. Rather, it can be explored during teaching, and after teaching in a variety of ways. 
Techachaicherdchoo Teerawut (2011) stated that taking feedback from students is the most effective tool to measure their satisfaction. On the contrary, while discussing the cause of dissatisfaction of students (M. Nauman et. al, 2010) highlighted the outdated teaching strategies and learning aids that are still using by pedagogues in many institutions and are no more functional to attain students' satisfaction towards teachers' teaching skills. They further added that even the newly formed reforms by educational authorities are incapable to satisfy students with their learning experience. The stated reason for students' dissatisfaction with most of the researchers is the traditional grading system and conventional assessment styles used by the teachers.

Shulman, L.S. (1987) indicated that besides subject-matter expertise the pedagogical content knowledge $(\mathrm{PKC})$ is required for effective teaching and the satisfaction of students. Also, the quality of teaching largely depends on the efficient use of pedagogical content knowledge in classroom practices. Thus, to apply the pedagogical content knowledge, the teacher must have to develop pedagogical skills. Sonia Guerriero also mentioned in her report that (Shulman, 1987) highlighted the two main concepts (general pedagogical knowledge \& pedagogical content knowledge) while classifying seven categories of teacher's knowledge.

Many of the effective teaching skills come under the umbrella of Pedagogical skills, i.e. Classroom management skills, Knowledge of Curriculum, Quality teaching, Differentiated instruction, Instructional Assessment, Use of appropriate and effective teaching strategies, etc.

Classroom management skills refer to all those expertise that an effective teacher possesses to make a smooth transition of classroom activities, to set an appropriate layout of the classroom, to motive students for active participation, to address on-task and off-task behaviors appropriately, to use teaching materials efficiently and to ensure students' satisfaction towards their learning experience. (Allison et. al, 2019) reported the positive impact of teachers' effective classroom management skills on students' behavior, academic performance, learning outcomes, and studentteacher relationships. This practice further leads to attaining students' satisfaction with classroom practices and teachers' pedagogical skills. Adeyemo (2012) also found that there is a positive relationship between students' achievement and classroom management skills and (Griffith, 2002) affirmed his findings. However, the study of (M. Aliakbari et. al, (2015)) considers that there are the other factors also that have the influential impact of students' achievement besides using the management strategies effectively in the classroom. In the opinion of Shawer (2006), the teachers who practice classroom management strategies are the "assertive teachers" having the positive expectations towards the students, and most of the time they get succeed to attain the satisfaction of their students.

The curriculum can be defined as the road-map or framework for teachers to accomplish desired learning objectives. Therefore, curriculum thinking and its knowledge needs to be undertaken for the teachers to start to think about how to represent and structure a topic (Lambert, D. (2014a)). The knowledge of the curriculum helps teachers to teach more effectively and to engage students completely in the topic. CUREE (2012) emphasized acquiring curriculum knowledge for all teachers to ensure that they can make connections between the curriculum and the real world. This made students not only to own their learning but also to satisfy teachers' pedagogical skills. Techachaicherdchoo Teerawut (2011) also found the positive relationship of knowledge and curriculum with the students' satisfaction.

Quality teaching is also one of the tools that have a great impact on students' satisfaction. (Suarman et. al, (2013)). It denotes such expertise of teachers that they use to deliver the content in an effective, enjoyable, and memorable way to learners for the enduring understanding of the topic. This includes good delivery of the content, effective lesson planning, and the use of appropriate teaching strategies and tools. Self-efficacy among the teachers is considered one of the prime factors for enhancing the quality of teaching, Suarman (2015). The study of (Suarman et. al, (2013)) stated that assessing the quality of teaching does not only help teachers in their professional development 
but also assists in taking the direct measures of students' satisfaction during their learning journey. Suarman (2015) added that this satisfaction on account of teaching quality either affects positive or in a negative manner on students' academic achievements.

Assessment is defined as the collection of data that aids in making academic decisions. According to Stiggins (2005), classroom assessment opens up an opportunity of learning for both instructors and learners. It helps to bring progressive change in teaching-learning practices and assists in achieving instructional goals in a more appropriate manner. Many educationists believed that the use of assessment-related activities in the classroom highlights the prominent and worthwhile elements and hence possesses an influential impact on students' achievement goals (Ames, 1992; Harlen \& Crick, 2003). Stiggins (2005) suggested that the teachers may use a variety of assessment tools and strategies and ensure that they do not only assess students' skills and competencies but also increase their motivation to learn. The study of Hussain Alkharusi (2008) also affirmed the point and stated that this motivation of students has a great influence on their satisfaction towards the assessment practices. Furthermore, Mujahid Mohammed (2018) stated that an appropriate equilibrium between the use of formative and summative assessments provides an equal opportunity for students to participate and to express their satisfaction towards assessment strategies.

The quality of teaching and effectiveness of a teacher can be evaluated by observing the use of a variety of teaching strategies and learning tools that assists in facilitating students' learning and in creating a conducive learning environment. Yun Ho Shinn (1997) found a positive relationship between teaching strategies and students' academic goals and stated that the teaching strategies and learning aids made a real contribution in making a paradigm shift of today's classroom practices from teacher-centered to student-centered. The study further illustrates the benefits of using appropriate teaching strategies and highlights its remarkable contribution in attaining students' satisfaction that how they are addressing the learning needs of students having different learning profiles or learning abilities.

\section{RESEARCH METHODOLOGY}

The targeted respondents of this study will be the Secondary grades students of Govt. Schools of Ghotki (both Urban \& Rural). The sample size of this study will be approximately 200 students of grade 9th \& 10th of Govt. Schools of Ghotki. This means that the first 100 students will be from urban schools of Ghotki and the other 100 students will be from rural schools of Ghotki. The research design of this study will be the quantitative research in general and the SURVEY RESEARCH DESIGN methodology in particular. So for this study, a survey questionnaire will be adapted from the research study conducted by Nek Kamal Neop Yonus et al., in 2010. There will be a total of 20 questions in the questionnaire written in three languages (English, Urdu \& Sindhi). The questions will be cover the following domains of teachers' of teachers' pedagogical skills, i.e.: Subject-matter expertise, pedagogical content skills, classroom management skills, knowledge of curriculum, use of appropriate and effective teaching strategies, use of effective assessment tools and teacher-student (relationship) factors. The rating sale will be used to design a questionnaire, and the respondents would just have to choose an option for each question. The questionnaires will be filled manually (on papers). Among 200 participants, 50 students will be called for interview as per their expression of interest. The collected data and recorded responses will be kept confidential. At last, the data will be analyzed through Independent T-Test and Descriptive Analysis using SPSS Software. 


\section{FINDING AND DISCUSSION}

The obtained results and findings will be used will help to evaluate the satisfaction level of Students towards Teacher's pedagogical skills, i.e. Subject-matter expertise, pedagogical content skills, classroom management skills, knowledge of curriculum, use of a variety of teaching strategies, use of effective assessment tools and teacher-student (relationship) factors. This study will also identify and highlight the required pedagogical skills that must be possessed by every teacher (especially of secondary grades). Moreover, the study will facilitate the stakeholders to design such appropriate training and programs that will contribute to the enhancement of the pedagogical skills of teachers. All in all, the findings will assist the policymakers and school administration to make reforms that will help to overcome the issues of inappropriate knowledge of pedagogical skills among teachers and will provide them a complete guide to make the value addition in the professional growth of the teachers.

\section{CONCLUSION AND FURTHER RESEARCH}

A quality education system always contributes to the development and progress of a nation and the role of its teachers and their valuable services is remarkable in this regard. Such nations who consider that students are the architects of their future, they need to ensure the effectiveness and quality of their teachers and besides must take account of students' satisfaction towards them to obtain the desired outcomes in the future. Concerning National Education Policy 2019 and National Curriculum 2019, it is evident that in the market of development and advancement; the nations need qualified educators (not mere pedagogues) to satisfy the most valued customers (students) in the walk of pursuing the bright and enlightened future.

This study mainly focuses on the satisfaction level of students towards teachers' pedagogical skills that are equally imperative for both teachers and students in making future educational reforms for further improvement. Additionally, the findings of this study may contribute to highlighting the pedagogical skills that are essential for every teacher not only increasing the students' participation and motivation in the classroom activities but also their satisfaction level towards applied teaching methods. Furthermore, the results may provide the essential information and suggestions to the relevant bodies such as stakeholders, policymakers, academicians, curriculum designers, teaching faculties, educational higher authorities, and institutional management and administration. This study may prove to be a utilitarian tool in assisting to accomplish the educational goals of the nation.

\section{REFERENCES}

Suarman (2015). Teaching Quality and Students Satisfaction: The Intermediatory Role of Relationship between Lecturers and Students of the Higher Learning Institutes. DOI: 10.5901/mjss.2015.v6n2p626

Techachaicherdchoo Teerawut (2011). Undergraduate student's satisfaction toward the new education system in Thailand.

Muhammad Nauman Abbasi, Ali Malik, Imran Sharif Chaudhry (2010). A Study on Student Satisfaction in Pakistani Universities: The Case of Bahauddin Zakariya University, Pakistan. doi:10.5539/ass.v7n7p209

Suarman, Zahara Aziz, Ruhizan Mohammad Yasin (2013). The Quality of Teaching and Learning towards Satisfaction among the University. doi:10.5539/ass.v9n12p252

Mohammad Aliakbari, Bafrin Bozorgmanesh (2015). Assertive classroom management strategies and students' performance: The case of EFL classroom. http://dx.doi.org/10.1080/2331186X.2015.1012899 
Adeyemo, S. A. (2012). The relationship between effective classroom management and students' academic achievement. European Journal of Educational Studies, 4, 367-381.

Griffith, J. (2002). A multilevel analysis of the relation of school learning and social environments to minority achievement in public elementary schools. The Elementary School Journal, 102, 349-367. http://dx.doi.org/10.1086/esj.2002.102.issue-5

Shawer, S. F. (2006). Effective teaching and learning in general education and foreign language teaching methodology: Learners' cognitive styles, foreign language skills instruction, and teachers' professional development. Cairo: Dar El-Fikr El-Arabi.

CUREE (2012). Evaluation of Learning Away: Hypothesis 5: Teachers' pedagogical skills. London: Paul Hamlyn Foundation.

Sonia Guerriero, Teachers' Pedagogical Knowledge, and the Teaching Profession Background Report and Project Objectives.

Shulman, L.S. (1987). Knowledge and teaching: Foundations of the new reform. Harvard Educational Review, 57(1), 1-22.

Monoranjan Bhowmik, Bharati Banerjee (Roy), Jayasri Banerjee Vidyasagar (2013). Role of Pedagogy in Effective Teaching.

Doris Choy, Angela F. L. Wong, Sylvia Chong, Kam Ming Lim (2014). Beginning teachers' pedagogical skills and knowledge towards positive pedagogic teacher-student relationships. US-China Education Review.

Shinn, Yun Ho (1997). "Teaching strategies, their use and effectiveness as perceived by teachers of agriculture: A national study". https://lib.dr.iastate.edu/rtd/12244

Leyla Temizer a, Ali Turkyilmazb (2012). Implementation of student satisfaction index model in higher education institutions.

Hussain Alkharusi (2008). Effects of Classroom Assessment Practices on Students' Achievement Goals, Educational Assessment, 13:4, 243-266.

DOI: $10.1080 / 10627190802602509$

Ames, C. (1992). Classrooms: Goals, structures, and student motivation. Journal of Educational Psychology, 84, 261-271.

Harlen, W., \& Crick, R. D. (2003). Testing and motivation for learning. Assessment in Education:

Principles, Policy \& Practice, 10, 169-207.

Stiggins, R. J. (2005). Student-involved assessment FOR learning (4th Ed.). Columbus, OH: Merrill Prentice Hall.

Mujahid Mohammed (2018). Impact of formative and summative assessments on 1st year physiology university exam in Medicine. (V-3, Issue - 6, P. : 90 - 94)

Qashoa, S. H. (2013). Effects of teacher question types and syntactic structures on EFL classroom interaction.

Mona Yousef Al-Zahrani, Abdullah Al-Bargi (2017). The Impact of Teacher Questioning on Creating Interaction in EFL: A Discourse Analysis.

Doi: 10.5539/elt.v10n6p135

Tengku nor Rizan Tengku, Mohamad Maasum Nooreiny Maarof, Hamidah Yamat, Effandi Zakaria (2012). An investigation of teachers' pedagogical skills and content knowledge in a contentbased instruction context.

Tolera Negassa, Ziyn Engdasew (2017). The Impacts and Challenges of Pedagogical Skills Improvement Program at Adama Science and Technology University.

Allison F. Gilmour, Caitlyn E. Majeika, Amanda W. Sheaffer, and Joseph H. Wehby (2019). The Coverage of Classroom Management in Teacher Evaluation Rubrics.

Lambert, D. (2014a). Curriculum leadership and the knowledge-led school. In M.Y, Lambert, and M. Roberts (Eds), knowledge and the future school: Curriculum and social justice (pp.157187).

Zongzi Deng (2017). Pedagogical content knowledge reconceived: bringing curriculum thinking into the conversation on teachers' content knowledge

Gulay-Ogelman, H., \& Ersan, C. (2014). The effect classroom management strategies for preschool teachers has on peer relationships in children. Bartın University Journal of Faculty of Education, 3(2), 63-84. https://doi.org/10.14686/BUEFAD.201428172 